\title{
Reforms in Pharmaceuticals Self-sufficiency in Developing Countries
}

\author{
Ria Christine Siagian* and Hasbullah Thabrany
}

School of Public Health Universitas Indonesia; riachristinesiagian@yahoo.com

\begin{abstract}
Objectives: We explored several factors that could trigger domestic new drug development and incorporated them into a predictive model of an innovation policy. Method: We systematically searched the relevant literature and briefly reviewed the varying concept of innovation policy for stimulating drug development. Findings: New drug development involves the creation of an innovative drug that is not yet available in the country. Several factors that encourage domestic innovation were identified through push and pull mechanism strategies. Those predictive factors, which were grouped into two major categories (regulation and incentives), were then used to predict a model of an innovation policy. Improvement: Minimizing uncertainties in drug development by strengthening regulatory and incentive mechanisms are major catalysts that encourage pharmaceutical companies to invest more in drug development.
\end{abstract}

Keywords: Drug Development, Innovation Environment, Innovation Policy Models

\section{Introduction}

Pharmaceutical self-sufficiency has gained increasing attention in a number of countries after a resolution of World Health Assembly (WHA) 61.21 in 2008 highlighted a local production to promote innovation and improve drug access in developing countries $\frac{1,2}{2}$. This is believed as a guided approach to pharmaceuticals security that places political priorities ahead. Developing countries have deemed it necessary to provide sustainable access to more affordable drugs in their domestic markets ${ }^{1,3,4}$. An example of this, in March 2016, the Indonesian government, led by President Joko Widodo, announced its commitment to achieve domestic self-sufficiency in pharmaceutical products. This was followed by a regulation to initially begin development on biopharmaceuticals, vaccines, herbal extracts and active pharmaceutical ingredients. The blueprint for action has been established as a national strategy and set a goal of focusing pharmaceutical companies on specific research and development (R\&D).
The $2025 \mathrm{R} \& \mathrm{D}$ blueprint, released in the following year, includes three different time frames covering products' priority to be developed. However, this is a hard work since developing countries face structural and financial problems. In developing countries, the high cost of drugs remains to be a global concern ${ }^{5}$. Ideally, pharmaceutical companies should support drug accessibility in countries whose citizens are unable to afford expensive treatment. As the cost for a pharmaceutical company to create one drug is unlikely to be transparent, a shift in the approach to encouraging domestic new drug development is also needed. This is important since pharmaceutical companies prefer to develop a product that offers limited additional therapeutic benefit but offer substantial revenues ${ }^{6}$. In order to implement the principle of pharmaceuticals self-sufficiency, a country must build an independent national capacity to produce pharmaceuticals and utilize the nation's resources in a rational and integrated way. The need for domestic new drug development is clearly needed as improvements in healthcare depend on this

${ }^{*}$ Author for correspondence 
innovation and the policymakers need to create a positive investment environment for drug development $\mathrm{t}^{1-3}$.

To address a concern of government coordination to foster an enabling environment, there is a need to have a clear understanding of the innovation and challenges in constructing an innovative environment in developing countries. With those concerns, the aims of this literature review are to 1) identify factors that create an innovation environment for new drug development for market access; and 2) predict factors affecting innovation policies that influence domestic pharmaceutical companies to invest in the development of pharmaceutical products.

\section{Methods}

A review of published literature was done and obtained from internet searches to identify "drug development", "innovation environment", and "innovation policy models" for stimulating domestic new drug development. The literature, published in the last decade, was initially sourced from peer-reviewed journals, and then augmented with grey literature. Following the compilation of initial search results, titles and abstracts were first screened for relevant articles addressing drug development. After that, the articles related to the title were reviewed to identify factors encouraging drug development and affecting innovation policies. The selected articles were used to further predict policy models for drug development. Articles in which the main outcome measure was not drug development per se were also included as long as they met the criteria of innovation environment and innovation policy.

\section{Results}

In general, the terms "drug development" and "drug innovation" are used interchangeably as both of their aims are to provide new affordable domestic drugs. Drug innovation is part of the drug development process and success in drug development reflects on the success in drug innovation. Drug innovation involves finding a novel compound that produces a desirable effect and may be more relevant to high-tech drug development including biopharmaceuticals, whilst drug development is the process of providing evidence of the effect of the drug in humans. Drug development includes several stages that could be conducted in different locations ${ }^{7-}$.
For example, it is possible to conduct a phase-1 study in country of origin whilst conducting the others in other countries. As part of these definitions may reflect collinearity, in this paper, the definition that was used for "drug development" is the creation of an innovative drug that is not yet available in the country and is developed domestically. A major challenge in drug development is making early go or no-go decisions from the identification of a potential therapeutic agent offered by the engines of high-throughput discovery to marketing a new drug product. It is widely known that the entire development cycle of a single drug, from research to marketing, is a complex, lengthy and costly process that offers no certainty in producing promising compounds. Unlike many other market-driven industries, drugs are highly regulated by governments as they are not classified as ordinary consumer products. Consumers do not make decisions as to when to use drugs or which drugs to use and weigh the risks and benefits of drugs. The effective use of new drugs has to improve the quality life of patients in order to improve their productivity, reduce healthcare costs and restore lifetime earnings. After the discovery of a new molecular entity, a new drug will then continue through a sequence of developmental stages, starting from the concept and the business decision to proceed, then the development of the required source materials, manufacturing process, analytical methods and non-clinical testing. Going through several decision gates, drug development needs to strategically identify potential drug behaviors in humans through a phased clinical development program to provide evidence for a Marketing Authorization license. A pharmaceutical company is required to submit evidence of the quality, safety and efficacy to regulatory agencies, which have the legal responsibility to review and ensure that the provided evidence is of acceptable quality, safety and efficacy. Once approved, the drug will then have access to the market ${ }^{7,9}$. Narayanan (2016) identified uncertainties in the process of drug development, including scientific uncertainties, usage uncertainties, and financial uncertainties The scientific uncertainties are related to potential changes in the risk-benefit profile during the development process and real practice; the usage uncertainties are associated with potential modifications of the indication or dosage of the drug by healthcare professionals; and the financial uncertainties are associated with the overall budget related to treatment ${ }^{10}$. Another perspective of 
uncertainties is associated with regulatory requirements that can potentially suspend the investment $1 \underline{11}-\underline{13}$.

Pharmaceuticals operate to maximize profits. A return of investment for their own R\&D capacities is highly expected. However, profits can conflict with public health objectives. It is expected for pharmaceutical companies to be able to produce high-quality and low-cost products. On the other hand, even if a company can demonstrate that a drug is safe and effective, it also has to show that its product can offer significant economic value ${ }^{14}$. In order to reduce costs during the drug development process, such as costs related to the product development's duration, costs related to unpromising candidates, or costs related to inefficiencies in the clinical trial process, the pharmaceutical companies have to focus on areas of high therapeutic need and productivity. These conditions are necessary but not sufficient for success in the rapidly changing environment. The competitiveness of companies depends on its capability to meet the demands of the market. This could be achieved by collaborating between stakeholders in the drug development process. The concept of network upon innovation was identified to offer the best mechanism to ensure success of a drug development. The innovation network recognizes that intensive communication, shared values and visions, mutual adjustment, and planning are likely to serve as a foundation to promote the transition from basic research to applied clinical research and commercialization ${ }^{3,4,14}$. Hence, the regulatory mechanisms might apply both to public health and businesses, such as public health needs (patient-oriented) and transparency of drug development costs. Reid \& Balasegaram (2016) considered that medical $\mathrm{R} \& \mathrm{D}$, which prioritized public health needs, had to be informed by the government, while transparency on $R \& D$ costs, providing realistic and fair pricing, was an important determinant in order for the government to promote needs-driven innovation. Fulfilling public health needs, it would be efficient if the entry of new drugs into their markets in the future could be facilitated by removing overly bureaucratic obstacles to drug registration and by making approval procedures efficient and effective $\mathrm{e}^{\underline{13}-1}$.

Conceptualizing pharmaceuticals self-sufficiency in relative terms, numerous studies have demonstrated that the environment and policies of innovation are important contributors to the development of pharmaceuticals. It is still possible to carry out drug development with a number of enabling factors that foster an innovative environment that encourages domestic drug development ${ }^{16}$. Concerning different capabilities of pharmaceutical companies in developing countries, several preferences of drug development to be conducted include long-term stage of finding a novel compound; mid-term stage of an active pharmaceutical ingredient development; shortterm to mid-term stage of an R\&D of bulk or intermediate; and short-term stage of formulation or filling (Figure 1).

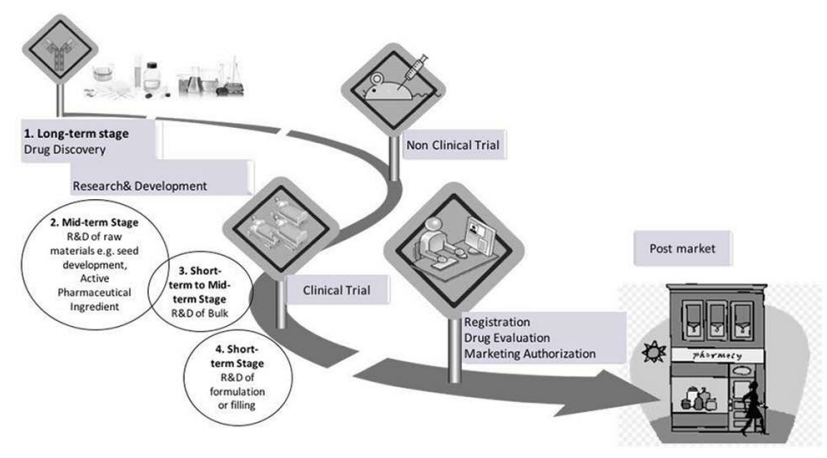

Figure 1. Stages of drug development.

Several factors cited that enable a domestic innovation environment were identified through two broad strategies known as push and pull mechanisms, to encourage and reward innovation at the same time. The enabling environment presented here encompasses incentives and regulation mechanisms. A balance of these 2 factors can encourage domestic innovation $\underline{2}-\underline{4}, \underline{15}-18$.

Push factors underline the domestic capabilities of pharmaceutical companies as the driving force behind development in the innovation process.

a. Scientific capabilities refer to available resources to understand the determinant and mechanism of diseases and then transform the synthesis to the market.

b. Investment in research and development (R\&D) refers to financial capacities. Financial constraints are related to a decrease in innovation.

c. Appropriate infrastructure is needed during the production of products and during phased clinical trials, including logistical arrangements and management. Infrastructure for data analysis and document preparation for regulatory purposes is needed when a drug reaches the next stage in the development process.

d. The promotion of partnerships and collaboration among stakeholders could reduce technical risk. 
Pull factors from government policies are considered to be the catalyst for domestic innovation.

a. Intellectual Property (IP) protection is considered as the principal incentive to invest in drug development, aimed to protect the innovative drug before it is registered and put into the market. This allows companies to temporarily exclude competition by filing several patents for a single drug. However, this is not related to the eligibility of drugs for commercialization ${ }^{?}$.

b. Diffusion of products is an essential factor for the survival of pharmaceutical companies.

Diffusion is the process by which an innovation is communicated through certain channels over time among the members of a social system, therefore innovation diffusion is a highly social process requiring organizations to facilitate the values of the products and clearly varied between products or technologies ${ }^{19}$.

c. Market opportunity is supported by a successful healthcare system in determining the level of distribution and access to the new drug (advanced market commitment).

d. Coherent and effective government innovation policies influence the length and the cost of the drug development process.

Several developing countries such as China, India, Argentine, Thailand, Uganda showed efforts to achieve self-sufficiency that were supported by innovation environment including drug regulation, scientific capabilities, infrastructure, R\&D financial support, partnership, IP protection, innovation diffusion, and market opportunities. A total of 3 innovation policy models were identified from the experiences of those countries, interlinking to each other, as shown in Table 1, 1,2,20,21.

1. Needs-driven innovation

Government and product developer's work together to prioritize diseases that require urgent attention. Innovation gaps are likely to be caused by attempts to focus on only four major disease areas, including central nervous system, cancer, cardiovascular and infectious diseases. Therefore, government promotes needs-driven innovation that protects access by supporting complementary $\mathrm{R} \& \mathrm{D}$, and then makes attempts to make costs transparent to negotiate a fair price while also guarding the mechanism in the framework of international trade rules. Government monitors the innovation profile of the country through estimating its innovation index which is determined by the number of innovations of new chemical entities.

2. Drug regulations

Drug regulations substantially drive the cost of new drugs. It is in every stakeholder's interest to fast-track the regulatory process as swiftly and effectively as possible, without compromising safety and quality standards. Government regulatory

Table 1. Policy model for domestic drug development

\begin{tabular}{|c|c|c|c|c|c|}
\hline $\begin{array}{l}\text { Innovation } \\
\text { Policy }\end{array}$ & India & China & Argentina & Thailand & Uganda \\
\hline $\begin{array}{l}\text { - Needs- } \\
\text { driven } \\
\text { innovation }\end{array}$ & $\begin{array}{l}\text { - Policy for } \\
\text { procurement of } \\
\text { locally produced } \\
\text { essential } \\
\text { medicines. } \\
\text { - Export of generic } \\
\text { formulated } \\
\text { products to high- } \\
\text { value developed } \\
\text { country markets. } \\
\text { - Developing } \\
\text { and promoting } \\
\text { scientific talent. }\end{array}$ & $\begin{array}{l}\text { - Pharmaceutical } \\
\text { sector policy to } \\
\text { linkage with the } \\
\text { Universal Health } \\
\text { Coverage } \\
\text { - Industrial policy } \\
\text { for financial } \\
\text { support, } \\
\text { infrastructures, } \\
\text { trained human } \\
\text { resources, basic } \\
\text { resources, } \\
\text { subsidies, tax }\end{array}$ & $\begin{array}{l}\text { - Regulation to prescribe } \\
\text { medicine by generic } \\
\text { name or international } \\
\text { nonproprietary name } \\
\text { (INN) } \\
\text {-Commitment to } \\
\text { purchase vaccines. } \\
\text { - Elimination of price } \\
\text { controls, reduction } \\
\text { of tariff protection, } \\
\text { elimination of } \\
\text { the prohibition } \\
\text { against patents for } \\
\text { pharmaceutical } \\
\text { products } \\
\text { - Industrial policy for } \\
\text { technology transfer to } \\
\text { the country. }\end{array}$ & $\begin{array}{l}\text { - Pharmaceutical } \\
\text { sector policy to } \\
\text { linkage with the } \\
\text { Universal Health } \\
\text { Coverage } \\
\text { - Self-reliance } \\
\text { and vaccine } \\
\text { supply security } \\
\text { for nationwide } \\
\text { immunization } \\
\text { program and } \\
\text { domestic supply }\end{array}$ & $\begin{array}{l}\text { - Policy for } \\
\text { procurement of } \\
\text { locally produced } \\
\text { essential drugs. } \\
\text { - Science and } \\
\text { Technology } \\
\text { Policy to guide } \\
\text { the science and } \\
\text { technology } \\
\text { development } \\
\text { policy effort. }\end{array}$ \\
\hline
\end{tabular}




\begin{tabular}{|c|c|c|c|c|c|}
\hline $\begin{array}{l}\text { Drug } \\
\text { Regulation }\end{array}$ & $\begin{array}{l}\text { - A coordination of } \\
\text { central and state } \\
\text { government regulatory } \\
\text { controls. } \\
\text { - Government } \\
\text { maintaining a system } \\
\text { of price controls on } \\
\text { essential medicines. } \\
\text { - Government promoting } \\
\text { the concept of the } \\
\text { pharmaceutical cluster. } \\
\text { - A compulsory } \\
\text { license to a patented } \\
\text { pharmaceutical product. }\end{array}$ & $\begin{array}{l}\text { - The strengthening } \\
\text { of regulatory } \\
\text { controls for } \\
\text { facilities, product } \\
\text { quality, safety } \\
\text { and efficacy, } \\
\text { procurement and } \\
\text { pricing system. } \\
\text { - Regulation for } \\
\text { environmental } \\
\text { safety }\end{array}$ & $\begin{array}{l}\text { - Regulatory controls } \\
\text { for facilities (member } \\
\text { of PIC/s), clinical } \\
\text { trial authorization } \\
\text { / bioequivalence, } \\
\text { marketing } \\
\text { authorization (safety } \\
\text { and efficacy) } \\
\text { - A governmental } \\
\text { system for } \\
\text { granting marketing } \\
\text { authorization by } \\
\text { similarity }\end{array}$ & $\begin{array}{l}\text { - The strengthening of } \\
\text { regulatory controls } \\
\text { for facilities, } \\
\text { product quality, } \\
\text { safety, and efficacy. }\end{array}$ & $\begin{array}{l}\text { - The strengthening } \\
\text { of regulatory } \\
\text { controls for } \\
\text { facilities, product } \\
\text { quality, safety, and } \\
\text { efficacy. }\end{array}$ \\
\hline Partnership & $\begin{array}{l}\text { - The Government of } \\
\text { India, in cooperation } \\
\text { with the private } \\
\text { sector, establishing } \\
\text { a pharmaceutical } \\
\text { promotion body, in } \\
\text { support of the export } \\
\text { sector of the country. } \\
\text { - A joint ownership of } \\
\text { inventions with private } \\
\text { sector. }\end{array}$ & $\begin{array}{l}\text { - Laws and } \\
\text { regulation } \\
\text { addressing inter- } \\
\text { institutional/ } \\
\text { agency } \\
\text { coordination. }\end{array}$ & $\begin{array}{l}\text { Collaboration } \\
\text { between domestic } \\
\text { and multinational } \\
\text { laboratories } \\
\text { for: know-how; } \\
\text { knowledge transfer; } \\
\text { and strategic } \\
\text { alliances with } \\
\text { universities and } \\
\text { public research } \\
\text { centres. }\end{array}$ & $\begin{array}{l}\text { - Strategic } \\
\text { collaborations } \\
\text { between vaccine } \\
\text { manufacturers } \\
\text { through joint } \\
\text { development and } \\
\text { licensing. } \\
\text { - Collaboration } \\
\text { with WHO for } \\
\text { technology transfer } \\
\text { of specific vaccine } \\
\text { development }\end{array}$ & $\begin{array}{l}\text { - Strategic } \\
\text { collaborations } \\
\text { between vaccine } \\
\text { manufacturers } \\
\text { through joint } \\
\text { development and } \\
\text { licensing. }\end{array}$ \\
\hline
\end{tabular}

mechanisms have to minimize uncertainties in the drug development process and ensure a stable and predictive regulatory environment. The government should then strategically implement regional or international harmonization to reduce barriers to the access of the drugs while redundant assessment might be conducted for value-added assessment in the country $\underline{12,13,22}$. In Stewart (2010) paper, it offered a model of balancing between flexibility in regulatory compliance, sufficient information to promote innovation to the market and stringency in compliance innovation.

3. Government encourages public-private partnerships (PPP) to fill gaps in health needs as well as provide funds to universities (Figures 2 and 3 ).

A PPP should offer a way to optimize public health outcomes. The government needs to attempt to negotiate in order to develop a common understanding among stakeholders to ensure that the partnership is truly in the interests of public health where additional partners may be added when necessary. Engaging with international collaboration to have access to specialized technology is an alternative way of know-how transfer led by initiatives

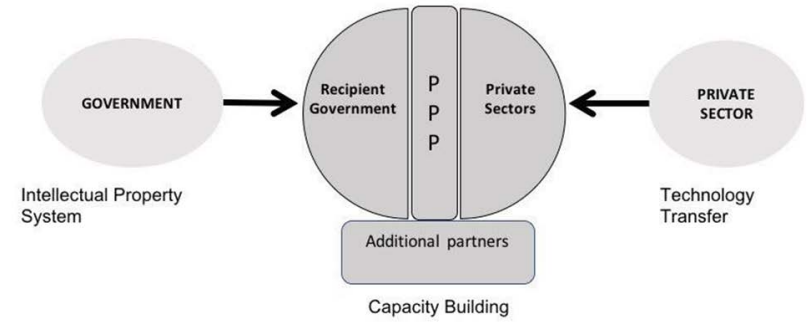

Figure 2. Proposed PPPs model in developing countries following the principle of a hybrid cooperation adapted from Siagian and Osorio (2018).

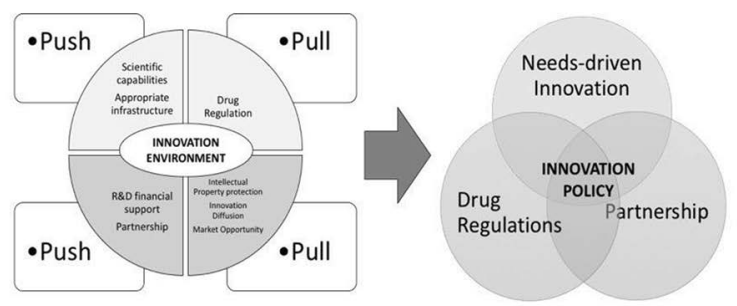

Figure 3. Factors affecting an innovation policy to selfsufficiency in drug development. 
to have a domestic drug development. Collaboration between private sector and the government could identify new drug candidates that meet public health needs and make a drug more affordable. Strategies in coordinated pricing and communication amongst stakeholders may extend the research pipelines thereby broadening access to the market ${ }^{7} \underline{23}$. As partnerships operate in an area of uncertainty, risk and unexpected outcomes out of a drug development, they therefore need to promote clear and effective mechanism focused on public interests, as is defined in the agreements ${ }^{16,24}$. At this stage, a mechanism to prevent risks to integrity sectors should be put in place by establishing ethical criteria and specific measures to identify and address risk of fraud and corruption in the public and private ${ }^{16}$.

\section{Conclusion}

A sustained government commitment to self-sufficiency in producing domestic pharmaceuticals in a timely manner and to meet all regulatory requirements should be reflected in the innovation policies to support drug development. Given the number of possible models that can be incorporated into an innovation policy, a decision framework is needed to help select an effective policy which encompasses incentives and regulation mechanisms. Despite challenges in developing drugs, several major approaches to foster domestic drug development have sought for the best innovation policy model.

This study has several limitations and a number of important questions that were unaddressed and deserved comment. Examples of country-specific innovation using different types of approved drugs were not examined. The pharmaceutical market with varying patent monopolies or government purchasing power also needs to be analyzed before adopting innovation strategies effectively in the country, as the government might have institutional bottlenecks that need to be addressed.

\section{References}

1. Local production for access to medical products: developing a framework to improve public health. World health Organization; 2011. p. 1-78.

2. Local production of pharmaceuticals and related technology transfer in developing countries. World health Organization; 2011. p. 1-326.
3. Local production and access to medicines in low- and middle-income countries. World health Organization; 2011. p. $1-56$.

4. Trends in local production of medicines and related technology transfer. World health Organization; 2011. p. 1-204.

5. Stevens $\mathrm{H}$, Huys I. Innovative approaches to increase access to medicines in developing countries. Frontiers in Medicine. 2017; 4:1-6.

6. Reid J, Balasegaram M. Research \& development in the dark: what does it take to make one medicine? And what could it take? ClinicalMicrobiologyand Infection.2016;22(8):655-7. https://doi.org/10.1016/j.cmi.2016.06.012. PMid:27373528

7. Petrova E. Chapter 2 Innovation in the pharmaceutical industry: The process of drug discovery and development. Innovation and Marketing in the Pharmaceutical Industry; 2014. p. 19-81.

8. Osakwe O. Chapter 2 - Trends in innovation and the business of drug discovery. Social Aspects of Drug Discovery, Development and Commercialization; 2016. p. 29-55. https://doi.org/10.1016/B978-0-12-802220-7.00002-8

9. Elhassa GO. Drug development: Stages of drug development. Journal of Pharmacovigilance. 2015; 3(3):140-2. https://doi.org/10.4172/2329-6887.1000e141

10. Narayanan S. Demonstrating the value of medicines: Evolution of value equation and stakeholder perception of uncertainties. Journal of Market Access and Health Policy. 2016; 4(1):1-3. https://doi.org/10.3402/jmahp.v4.31670. PMid:27489585. PMCid:PMC4956726

11. Isasi $\mathrm{R}$, Rahimzadeh $\mathrm{V}$, Charlebois $\mathrm{K}$. Uncertainty and innovation: Understanding the role of cell-based manufacturing facilities in shaping regulatory and commercialization environments. Applied and Translational Genomics. 2016; 11:27-39. https://doi.org/10.1016/j. atg.2016.11.001 PMid:28018847. PMCid:PMC5167439

12. Stewart L. The impact of regulation on innovation in the United States: A cross-industry literature review. Information Technology and Innovation Foundation. 2010; 9(1):1-29.

13. Abashidze AK, Malichenko VS, Malichenko SB. The role of pharmaceutical security in realization of the right to health. Indian Journal of Science and Technology. 2016; 9(39):1-8.

14. Kaitin KI. Deconstructing the drug development process: The new face of innovation. Clinical Pharmacology and Therapeutics. 2010; 87(3):356-61. https://doi.org/10.1038/ clpt.2009.293. PMid:20130565. PMCid:PMC2953249

15. The new frontiers of biopharmaceutical innovation. Geneva Switzerland [Internet]. [cited 2012 ]. Available from: https://www.ifpma.org/resource-centre/the-new-frontiersof-biopharmaceutical-innovation/.

16. Siagian RC, Osorio JE. Novel approaches to vaccine developmentinlower-middleincomecountries. InternationalJournal 
of Health Governance Information. 2018; 23(4):288-300. https://doi.org/10.1108/IJHG-03-2018-0011

17. Grace C, Kyle M. Comparative advantages of push and pull incentives for technology development: Lessons for neglected disease technology development. Technological Innovation Incentives. 2009; 6:147-51.

18. Mueller-Langer F. Neglected infectious diseases: Is push and pull incentive mechanisms suitable for promoting drug development research? Health Econ Policy Law. 2013; 8(2):185-208.https://doi.org/10.1017/S1744133112000321. PMid:23343639. PMCid:PMC3592259

19. Rekers JV. What triggers innovation diffusion? Intermediary organizations and geography in cultural and science-based industries. Environment and planning. C, Government and Policy. 2016; 34(6):1058-75. https://doi. org/10.1177/0263774X15625226

20. Indian policies to promote local production of pharmaceutical products and protect public health [Internet]. [cited
2017]. Available from: https://papers.ssrn.com/sol3/papers. cfm?abstract_id=2963867.

21. China policies to promote local production of pharmaceutical products and protect public health. World health Organization; 2017. p. 1-60.

22. Ahonkhai V, Martins SF, Portet A, Lumpkin M, Hartman D. Speeding access to vaccines and medicines in low- and middle-income countries: A case for change and a framework for optimized product market authorization. PLoS One. 2016; 11(11):1-13.https://doi.org/10.1371/journal. pone.0166515. PMid:27851831. PMCid:PMC5112794

23. Pharmaceutical production and related technology transfer. World health Organization; 2011. p. 1-92.

24. Jensen $\mathrm{O}, \mathrm{Wu} \mathrm{X}$. The hybrid model for economic regulation of water utilities: Mission impossible? Utilities Policy. 2017; 48:122-31. https://doi.org/10.1016/j.jup.2016.04.017 